\title{
Özel okul yatırımları için Türkiye'deki 81 ilin çok kriterli karar verme yöntemleri ile stratejik analizi
}

\author{
Ali ÖZDEMİR ${ }^{[*]}$ \\ Fatih TÜYSÜZ $Z^{[*]}$
}

\begin{abstract}
Öz
Türk eğitim sisteminin her kademesinde, eğitim-öğretim veren özel okulların varlığı, eğitimöğretime olumlu katkı sağlamaktadır. Özel okullar, eğitimde bir rekabet ortamının oluşmasını sağlayarak, eğitim ortamlarının niteliğini artmasını sağlayabilmekte ve bu sebeple bu okullara olan talep artmaktadır. Eğitim sektörü gelişmeye oldukça müsait bir sektördür ve günümüzde özel okulların sayısı, devletin de bu okulları teşvik etmesiyle birlikte her geçen gün artmaktadır.

Bu çalışmada özel okul yatırımı yapmak isteyen girişimciler için özel okul yatırım yeri seçiminin kolaylaştırılması amacı ile Çok Kriterli Karar Verme metotlarından Analitik Hiyerarşi Süreci ve Gri ilişkisel Analiz yöntemleri kullanılarak karar vericilerin bilimsel verilere dayalı olarak rasyonel bir seçim yapabilmesi amaçlanmıştır. Bu amaçla ilgili alan yazın taraması ile ve uzman görüşleri alınarak özel okul yatırımları konusunda öncelikle temel alınacak kriterler belirlenmiş, ilgili kaynaklardan yararlanılarak elde edilen gerçek veriler, uzmanlarca atanan ağırlıklar dikkate alınarak Türkiye’deki 81 il özel okul yatırım yapılabilirliği açısından sıralanmıştır.
\end{abstract}

Anahtar kelimeler: Özel okul yatırımları, çok kriterli karar verme, Türkiye.

\section{Strategic analysis of $\mathbf{8 1}$ provinces in Turkey for private school investments using multiple criteria decision making methods}

\footnotetext{
Abstract

At every level of the Turkish education system, the presence of private schools provides a positive contribution to education and training. Private schools for which demand is increasing are able to

${ }^{[*]}$ Öğr. Gör. Dr., Marmara Üniversitesi, Atatürk Eğitim Fakültesi, Eğitim Bilimleri Bölümü, aliozdmr32@gmail.com, aozdemir@marmara.edu.tr

${ }^{[* *}$ Yrd. Doç. Dr., İstanbul Üniversitesi, Mühendislik Fakültesi, Endüstri Mühendisliği Bölümü,
} fatih.tuysuz@istanbul.edu.tr 
increase the quality of education by providing a competitive environment. The education sector has been a developing industry and today the number of private schools has been increasing everyday with the incentives of the government. In this study, it is aimed to facilitate the selection of private schools' location investment decision for the entrepreneurs who want to invest in private schools. It is also aimed that decision makers can make a rational decision based on scientific data by using two Multi Criteria Decision Making methods which are Analytical Hierarchy Process and Grey Relational Analysis methods. For this purpose, the criteria to be taken as the basis for private school investments were determined by literature review and expert opinions. Then, the actual data obtained from the related sources and the weights were assigned by the experts.

Keywords: Private school investments, multiple-criteria decision making, Turkey.

\section{Türkiye'de özel öğretim kurumları ve özel okul sektörü}

Ülkemiz hukukuna göre devlet, vatandaşının yasal olarak eğitim ve öğretim hakkını sağlamak zorunda olup bunu MEB aracılığıyla eğitim ihtiyacını karşılayacak kurum ve kuruluşları kurarak ve işleterek gerçekleştirir. Diğer taraftan özel öğretim kurumları/özel okullar, devletin anayasal bir zorunluluk olarak üstlendiği bu yükümlülüğün hem bir kısmını alarak, hem de ödediği vergilerle, sağladığı istihdamla ve yaptığı yatırımlarla ülke ekonomisine katkı sunmaktadırlar (Çelik, 2006).

Özel Öğretim Kurumları belli bir ücret karşılığında eğitim hizmeti veren kurumlar olup 5580 sayılı Öğretim Kurumları Kanunu hükümlerine göre faaliyetlerini sürdürmektedirler (MEB, 2016). Genel olarak değerlendirildiğinde devlete ait resmi okullar dişında kalan ve giderleri devlet bütçesinden karşılanmayan eğitim-öğretim kurumları, özel okul olarak adlandırılmaktadır. $\mathrm{Bu}$ kurumlar okulöncesinden başlayarak üniversiteye kadar eğitim-öğretim hizmeti sunmakta olup sahipleri ve kurucuları hem gerçek kişiler hem de sivil toplum kuruluşları olabilir. Mevcut durumda Millî Eğitim Bakanlığı’nın denetim ve gözetimi altında olmak üzere yerli ya da yabancı, gerçek veya tüzel kişiler tarafından kurulmuş olup bir ücret karşılığında örgün eğitim-öğretim veren tüm özel okullar, esas olarak aynı yasal düzenlemeler içinde yer almaktadırlar (Uygun, 2003).

Özel okullar 5 grupta incelenebilir. Bunlar (MEB, 2012);

- Özel Türk Okulları,

- Özel Yabanci Okullar,

- Özel Azınlık Okulları,

- Özel Eğitim Okulları,

- Milletlerarası Özel Öğretim Kurumları’dır.

Özel okullar devlet okullarından başlıca farkı işletme statüsüne sahip olmaları, sahiplerinin kurucu ya da yönetim kurullarından oluşmasıdır. Bu açıdan değerlendirildiğinde sahip oldukları işletme fonksiyonlarının tümü piyasa ve rekabet koşulları içerisinde ele alınmaktadır. 
Küreselleşmenin getirdiği rekabet koşullarında hizmet sunduklarından dolayı, değişen çevre koşullarına uyum sağlama, iç (çalışan) ve dış müşteri (öğrenci-veli) memnuniyetini sağlama, etkili karar alma, kaliteli (vasıflı) çalışan istihdamı temini gibi birçok özel işletmecilik kurallarını etkin bir biçimde yerine getirme yeteneğine sahip olmak zorundadırlar (Demirci, Taşkın ve Yuca, 2006). Teknolojiyi de yakından takip eden özel okullar, teknoloji ile eğitim süreçlerini entegre ederek öğrenme ortamlarında öğrenci ve velilerine çeşitli araştırma, inceleme ve değerlendirme yapma imkânı sunarak kaliteli eğitim ve öğretim beklentilerini karşılamaya çalışmaktadırlar (Subaşı ve Dinler, 2003).

1739 sayll Türk Milli Eğitim Temel Kanunu, 1. ve 2. maddede belirtilmiş olan Türk Milli Eğitimi’nin amaçlarını gerçekleştirmek ve bu amaçlar doğrultusunda yurttaşlar yetiştirme amacı, özel okulların da amaçları arasında yer almaktadır. Özel okullar devlet okulları gibi Milli Eğitim Bakanlı̆̆ına bağlı olarak hizmetlerini vermelerine rağmen yapısal olarak aralarında bir takım farklılıklar bulunmaktadır. Bu farklar genel hatlarıyla şu şekilde belirtilebilir (Başkaya, 2006):

- Özel okullar şahıs, ortaklar veya bir kurum tarafından kurulabileceği gibi, resmi okullar devlet tarafindan kurulur.

- Özel okullar kar-zarar hesabı yapmak zorunda olmasına rağmen resmi okullar böyle bir kaygı taşımamaktadır.

- Özel okullar sunmakta oldukları eğitim-öğretim hizmetlerini karşıllğında velilerden ilgili yönetmelik doğrultusunda belirledikleri yıllık belirli bir ücret talep etmektedirler. Resmi okullar ise eğitim-öğretimi, Milli Eğitim Kanunu’na göre ücretsiz olarak sunmaktadırlar.

- Özel okullar istihdam ettikleri öğretmen ve personel ücretlerini kendi kaynaklarınca karşllamaktayken resmi okullar merkezi atama yolu ile istihdam oluşturarak, öğretmenlerin ve diğer personelin ücretleri de kamu bütçesi tarafından karşılanmaktadırlar.

Türk eğitim sisteminin her kademesinde, eğitim-öğretim veren özel okulların varlığı, eğitimöğretimde olumlu bir rekabete de yol açmaktadır. Bu rekabet yalnız resmi okullarla değil, aynı zamanda özel okulların kendi aralarında da gerçekleşmekte bu da eğitimde kaliteyi arttırmaktadır. Özel okullara yönelik olarak olumlu ve olumsuz yönde değerlendirmeler yapılmaktadır. Olumlu değerlendirmelere kısaca değinecek olursak (Uygun, 2003);

- Öğrenci aileleri ve girişimciler devletin kamu eğitimi giderlerinin bir kısmını yüklenerek devlete destek olmaktadırlar.

- Eğitim-öğretimde rekabet ortamı oluşturduğundan bu alanda nitelik artışına sebep olmaktadirlar.

- Yeterli maddi imkâna sahip olan öğrencilerin devlete yük olmadan eğitimlerini sağlamakla birlikte, sağladıkları burs imkânları ile maddi durumu yetersiz ve akademik başarıları yüksek öğrencilere daha iyi eğitim alma fırsatı sunmaktadırlar.

- Devletin denetimi ve gözetimi altında millî eğitimin temel amaç ve ilkelerine uygun, en az bir yabancı dil bilen çağdaş becerilerle donanmış nitelikli bireyler yetiştirmektedirler.

Özel okullarla ilgili yapılan olumsuz değerlendirmelere bakıldığında ise (Uygun, 2003); 
Bu okullar,

- Küresel, rekabete dayalı kapitalist düzenin destekleyici uzantıları olarak zengin çocuklarını eğitmek için kurulmuş olup amaçları eğitimden ziyade kar sağlamaktır.

- Eğitimde firsat eşitliğini bozarak haksız bir rekabet ortamı oluşturmaktadırlar.

- Devletin amaçladığı insan tipini yetiştiremedikleri gibi milli ve manevi değerlerden uzak, yabancı hayranı, tutucu ve gerici bireyler yetiştirmektedirler.

- Hukuki açıdan Öğretim Birliği Yasasına aykırı olan okullardır.

Geçici bazı sorunlarına rağmen her geçen gün bu okullara, talep ve ilgi artmakta ve paralelinde özel okullar sayıca çoğalmaktadır.

Gelişmiş ülkelerin özel okullaşma oranlarına bakıldığında \%10-15 seviyelerinde olduğu, AB'de ise öğrencilerin \%14'ünün eğitimlerini özel okullardan aldığı görülmektedir. Özel öğretim oranları Belçika, Fransa ve Almanya birlikte değerlendirildiğinde \%47, Belçika-Flaman grubunda ise 62.7’ dir. İspanya ve Malta’da özel öğretim oranı \%30, Fransa ve Birleşik Krallık' ta \%21 Portekiz'de \%17' dir. Bu ülkelerde özel ögrretim oranlarının yüksek olmasında en önemli faktör kamu tarafından desteklenen özel okulların oranlarının yüksek olmasıdır (TOBB, 2014).

Tablo 1

Eğitimde Ülkelerin Özel Sektör Payları (OECD-20 / 2)

\begin{tabular}{|c|c|}
\hline Ülkeler & Özel Sektörün Eğitimdeki Pay1 \\
\hline Kore & 39.5 \\
\hline ABD & 31.6 \\
\hline Avustralya & 27 \\
\hline Japonya & 25.8 \\
\hline Meksika & 19.5 \\
\hline Yeni Zelanda & 19.3 \\
\hline Almanya & 17.7 \\
\hline İngiltere & 16.1 \\
\hline Slovakya & 12.9 \\
\hline İspanya & 12.9 \\
\hline Çek Cumhuriyeti & 12.7 \\
\hline
\end{tabular}

Tablo 1'de yer alan eğitimde özel sektörün payları incelendiğinde daha liberal geleneğe yakın ekonomilerde eğitimde özel sektör paylarının daha yüksek olduğu görülmektedir. 
Marmara Üniversitesi Atatürk Eğitim Fakültesi Eğitim Bilimleri Dergisi • Journal of Educational Sciences

Yıl: Ocak 2017 • Cilt-Sayı 45 • ISSN: I300-8889・ ss. 93-I I4

Tablo 2

Bazı Ülkelerde Özel Okul \% Oranları (2013 OECD Eğitime Bakış)

\begin{tabular}{|c|c|c|c|c|}
\hline Sira & Ülkeler & Özel İlkokul & Özel Ortaokul & Özel Lise \\
\hline 1 & Şili & 58.9 & 53.7 & 60.8 \\
\hline 2 & Belçika & 53.8 & 60.7 & 57.1 \\
\hline 3 & İspanya & 31.6 & 31.1 & 21.1 \\
\hline 4 & Avustralya & 31.1 & 35.6 & 34.8 \\
\hline 5 & Fransa & 14.8 & 21.9 & 31.5 \\
\hline 6 & Danimarka & 14.4 & 26.8 & 1.8 \\
\hline 7 & OECD Ortalaması & 10.7 & 14.3 & 19 \\
\hline 8 & AB Ortalaması & 9.9 & 13.6 & 17.2 \\
\hline 9 & ABD & 8.7 & 8.3 & 8.2 \\
\hline 10 & Çin Halk Cumhuriyeti & 5.3 & 8.3 & 11.8 \\
\hline 11 & Birleşik Krallık & 5.1 & 28.7 & 51.7 \\
\hline 12 & Almanya & 4.3 & 9.3 & 7.8 \\
\hline 13 & Finlandiya & 1.6 & 4.6 & 17.8 \\
\hline
\end{tabular}

Tablo 2'de bazı ülkelerin özel sektörün eğitimde aldığı pay belirtilmektedir. Buna göre ülkeler arası farklılıklara karşın daha üst eğitim düzeylerinde eğitim sektörü payının biraz daha yüksek olduğu dikkati çekmektedir.

Mevcut hükümet programında özel okullaşma oranının yükseltilmesi amaçlanmaktadır. Son kanuni düzenlemelerde özel okullarda okuyan öğrencilere destek verilmesi hükmü sektör tarafından olumlu olarak değerlendirilmektedir.

Tablo 3

Özel Öğretim Kurumlarında ve Öğrenci Sayılarında Büyüme

\begin{tabular}{|c|c|c|}
\hline \multicolumn{2}{|c|}{ Özel Öğretim Kurumlarında Öğrenci Sayısında Büyüme } & Özel Öğretim Kurumları Sayısında Büyüme \\
\hline Ylllar & Öğrenci sayıs1 & Kurum sayıs1 \\
\hline 2000 & 246.514 & 1.788 \\
\hline 2001 & 260.193 & 1.897 \\
\hline 2002 & 265.680 & 1.887 \\
\hline 2003 & 222.992 & 1.399 \\
\hline 2004 & 245.414 & 1.679 \\
\hline 2005 & 261.570 & 1.893 \\
\hline 2006 & 305.862 & 1.799 \\
\hline 2007 & 360.042 & 2.057 \\
\hline 2008 & 386.797 & 2.353 \\
\hline 2009 & 394.253 & 2.391 \\
\hline 2010 & 422.702 & 2.274 \\
\hline
\end{tabular}




\begin{tabular}{|c|c|c|}
\hline 2011 & 458.118 & 2.750 \\
\hline 2012 & 495.000 & 3.063 \\
\hline 2013 & 566.000 & 4.392 \\
\hline 2014 & 654.000 & 5.118 \\
\hline 2015 & 823.515 & 7.474 \\
\hline 2016 & 1.174 .409 & 9.581 \\
\hline Toplam Artış & 5.4 Kat & 4.8 Kat \\
\hline
\end{tabular}

Kaynak: MEB 2000-2016 verilerinden araştırmacılar tarafından derlenmiştir.

Tablo 3’te gösterildiği üzere özel okul sektöründe öğrenci sayısı değişimine bakıldığında 14 yılda 246.000'den 1.174.409'e yükseldiği görülmektedir. Buradaki artışın önemli bir bölümünü okul öncesi öğrenci sayısındaki artış oluşturmaktadır.

Tablo 4

Yıllara Göre Özel Öğretimin Okul ve Öğrenci Sayılarının Toplam lçindeki Payı

\begin{tabular}{|c|c|c|c|c|c|}
\hline Y11 & $\begin{array}{c}\text { Resmi Öğrenci } \\
\text { Say1s1 }\end{array}$ & $\begin{array}{c}\text { Özel Öğrenci } \\
\text { Sayıs1 }\end{array}$ & $\begin{array}{c}\text { Toplam Öğrenci } \\
\text { Sayıs1 }\end{array}$ & $\begin{array}{c}\text { Özel Öğrenci } \\
\text { Artı̧ Oranı (\%) }\end{array}$ & $\begin{array}{c}\text { Özel Öğrenci / } \\
\text { Toplam Öğrenci } \\
(\%)\end{array}$ \\
\hline $2006-2007$ & 13.873 .208 & 360.042 & 14.233 .250 & - & 2,53 \\
\hline $2007-2008$ & 13.784 .080 & 386.797 & 14.170 .877 & 7,43 & 2,73 \\
\hline $2008-2009$ & 14.074 .079 & 423.253 & 14.497 .332 & 9,43 & 2,92 \\
\hline $2009-2010$ & 14.688 .342 & 458.108 & 15.146 .450 & 8,24 & 3,02 \\
\hline $2010-2011$ & 15.164 .318 & 498.118 & 15.662 .436 & 8,73 & 3,18 \\
\hline $2011-2012$ & 14.821 .197 & 535.788 & 15.356 .985 & 7,56 & 3,49 \\
\hline $2012-2013$ & 15.239 .702 & 613.064 & 15.852 .766 & 14,42 & 3,87 \\
\hline $2013-2014$ & 15.228 .934 & 698.912 & 15.927 .846 & 14,00 & 4,39 \\
\hline $2014-2015$ & 14.950 .897 & 823.515 & 15.774 .412 & 17,83 & 5,22 \\
\hline $2015-2016$ & 14.540 .339 & 1.174 .409 & 15.714 .748 & 42,61 & 7,47 \\
\hline & & & & & \\
\hline
\end{tabular}

Kaynak: MEB Resmi İstatistik Kitapları.

Tablo 4’te son on yıldaki özel ve resmi okullarda eğitim alan öğrenci sayıları karşılaştırmalı olarak sunulmuştur. Buna göre 2006 yılından 2016 yılına kadarki on yıllık dönemde özel okullara devam eden öğrenci sayıları istikrarlı biçimde artış göstermektedir.

2015-16 eğitim-öğretim ülke genelinde 6.486 özel okul eğitim ve öğretim desteğinden yararlanmıştır. Öğrenci başına destek miktarı okulöncesinde 2.680, ilkokulda 3.220, ortaokulda 3.750, temel liselerde 3.220, ortaöğretimde (temel liseler hariç) 3.750 TL olduğu belirtilmektedir 
(Eğitim İzleme Raporu, 2016). Özel okullarda eğitim alan öğrenci sayılarındaki artı̧̧ın resmi okullardaki sınıf mevcutlarının azalmasını olumlu etkilediği söylenebilir (MEB, 2016).

\section{Özel okulların kuruluşu ve işletilmesi}

5580 sayılı Kanuna göre hizmet veren ve genel olarak özel öğretim kurumları olarak isimlendirilen özel okullar, özel dershaneler, özel kurslar, sürücü kursları, etüt merkezleri, hizmet içi eğitim merkezlerinin kuruluş/açılış faaliyetleri ve işlemleri Özel Öğretim Kurumları Yönetmeliği’ne göre yürütülmektedir. Açılış için gerekli olan standartların ne olacağı ise "Standartlar Yönergesi” ile belirlenmiştir. Özel öğretim kurumlarının açılış işlemleri sürecinde bakanlı̆̆ın denetim birimlerince, il sağlık birimlerince ve belediyelerin itfaiye müdürlüklerince gerekli incelemeler yapılarak uygunluk raporu verilmesi zorunludur.

Özel öğretim kurumlarında eğitim-öğretime başlanabilmesi için öncelikle kurum açma izni alınması gereklidir. 5580 saylı kanunun 3 üncü maddesi hükmü doğrultusunda özel öğretim kurumlarına kurum açma izni ile iş yeri açma ve çalışma ruhsatı verilir. İzin başvuruları ise ilgili milli eğitim müdürlügüne yapılır ve kurum açma izni alınmadıkça kuruma öğrenci kaydı yapılamaz. Kurum açma izni verilmesi, binanın kullanılış amaçlarına ve Bakanlıkça belirlenen standartlara uygun ve yeterli bulunmasıyla birlikte 5580 sayılı Kanun'da sayılan şartların yerine getirilmesine bağlıdır (MEB, 2007).

Özel okullarda öğrenim ücreti ve diğer ücretler, kurumlarca her yıl tespit edilerek ocak ayından itibaren en geç mayıs ayında ilân edilir. Tahsil edilecek ücretlerin nasıl tespit, tayin, ilân ve tahsil edileceği ise yönetmelikle belirlenmektedir. Kurumlar, mevcut öğrenci sayılarının en az yüzde üçünü ücretsiz okutmakla yükümlüdür. Bakanlık bu oranı yüzde ona kadar artırılabilmektedir (MEB, 2007).

Her ne kadar sadece kazanç sağlamak amacı ile faaliyet yürütülemeyeceği belirtilmiş olsa da (5580 sayılı kanun Madde 12) temelinde hür teşebbüs düşüncesi yatmakta olan özel okul işletmeciliği kurucu ya da kurucularının sermayelerini koydukları bir teşebbüs olması ve rekabet ortamında faaliyet göstermesinden dolayı, kâr elde etmemeleri düşünülemez. Bu sebeple, özel okul işletmeciliği devlet okullarından farklı olarak kârı da amaçlayarak faaliyet gösteren kuruluşlar olarak değerlendirilebilir (MEB, 2007).

Özel sektörün eğitime olan katkısı yadsınamaz. Eğitim alanında geleceğin şekillendirilmesi, planlanması ve uygulanabilir hale getirilmesi için özel okul sektörünün teşvik edilerek devlet desteklerinin artması ülkemizdeki eğitim niteliğinin artması bakımından önem arz etmektedir.

Özel Okullara yönelik teşvikler, 19 Haziran 2012 tarih ve 28328 sayılı Resmi Gazetede yayımlanan 2012/3305 sayılı Bakanlar Kurulu Kararı (Yatırımlarda Devlet Yardımları Hakkında Karar) ile 20 Haziran 2012 tarih ve 28329 sayılı Resmi Gazetede yayımlanarak yürürlüğe giren "Yatırımlarda Devlet Yardımları Hakkında Kararın Uygulanmasına İlişkin Tebliğ" hükümleri kapsamında uygulanmaktadır. Teşvik Belgesi müracaatları, valilik uygun görüş yazısı ile Ekonomi Bakanlığına yapılması gerekmektedir (MEB, 2012). 
Eğitim kurumlarını da kapsayan stratejik yatırımlarda istenen ölçütleri sağlayan yatırımcılar, bölgeler arası fark gözetilmeksizin, yatırım yeri tahsisi, KDV istisnası, vergi indirimi, sigorta primi ve sigorta primi işveren hissesi desteği, faiz desteği, KDV iadesi, gelir vergisi stopajı desteği, gümrük vergisinden muafiyet gibi teşvik ve desteklerden yararlanabilecektir. (Ekonomi Bakanlığı, Yatırımlarda Devlet Yardımları Hakkında Karar, 2012).

\section{Özel öğretim sektörü yatırım ortamı}

Son yıllarda özel okulların sayısının artması, bu kurumlarca sunulan burs imkânları ve devlet politikası olarak verilen teşvikler, sektördeki kurumların üstün performans gösterme çabasının bir sonucu olarak özel okullara olan ilgi ve talep giderek arttırmıştır.

Yeni teşvik sistemi kapsamında yer alan eğitim yatırımları arasında desteklenenler sadece özel okul yatırımlarıdır. Bunun dışında kalan eğitim yatırımları öncelikli yatırım kapsamına alınmamıştır. Politik kara vericilerin tarafından yaygın eğitim faaliyetleri için yapılacak yatırımlar desteklenmemiştir (TOBB, 2014).

Bölgesel bazda sunulan yatırım teşviklerinden yalnızca özel okul yatırımlarının öncelikli olarak yararlanması sağlanmış olmakla birlikte eğitim kurumlarının kendi mülkleri olan arsalar üzerinde okul yapmaları birçok şarta bağlanmıştır. Arsa sorunu yatırımcıların karşılaştığı en büyük engel olarak görünmektedir. Özel okul sektörü, ilgili makamlara yaptığı başvuru ve taleplerden bu güne kadar istediği sonucu alamamıştır. Bakanlığın merkez ve taşra teşkilatındaki yetkililer eğitim yatırımı konusunda resmi okulları öncelikli olarak düşünmekte ve sektörden gelen taleplere izin vermekte zorlanmaktadır.

Ülke genelinde 5580 sayılı Kanuna göre açlacak özel okul öncesi hizmet veren okullarını en az 10 derslik/oyun ve etkinlik alanı olması halinde verimli olacağı belirtilmektedir. Ayrıca Milli Eğitim Bakanlığı Standartlar Yönergesinde belirtilen şartlarla birlikte değerlendirildiğinde yatırım maliyeti hesaplanacak olursa (TOBB, 2014);

Milli Eğitim Bakanlığ Standartlar Yönergesi’ne göre, anaokulunda en az $10 \mathrm{~m}^{2}$ müdür odas1, kontenjanı 150'yi geçenlerde $10 \mathrm{~m}^{2}$ müdür yardımcısı odası, isteğe bağlı en az $10 \mathrm{~m} 3 / 3 \mathrm{~m}^{2}$ uyku odası, en az $15 \mathrm{~m}^{2}$ oyun ve etkinlik odası, öğrenci başına en az 1,5 $\mathrm{m}^{2}$ bahçe, isteğe bağlı yemek odası, engellilere ayrı kız ve erkeklere ayrı olmak üzere her 30 öğrenci için yaşına uygun bir tuvalet ve lavabo, bay bayan ayrı 30 öğretmene bir tuvalet ve lavabo, anaokulu bürolar dâhil asgari 20 bölmeden oluşacağı ve anaokulu binalarının ortalama $400 \mathrm{~m}^{2}$ olacağı söylenebilir.

Bahçe alanı için okulöncesi kurumlarında öğrenci başı 1,5 $\mathrm{m}^{2}$ alandan okul başına ortalama 200 $\mathrm{m}^{2}$ alan ayrılabilir. Bu durumda ortalama rakamlardan hareketle bir anaokulu için ayrılacak arsa asgari 500-600 m² olmalıdır. $500 \mathrm{~m}^{2}$ lik bir anaokulu arsası yerleşim birimlerine yakın bölgelerde ortalama 1.000.000TLyi bulacağı düşünülürse İnşaat maliyeti, hafriyat ve diğer maliyetlerde eklenirse 15 derslikli bir anaokulunun yaklaşık 1.000.000TL’ye mal olacağı söylenebilir. Orta büyüklükte bir anaokulunun tefriş maliyeti 500.000 TL alınabilir. Kendi binasında hizmet veren bir anaokulunu toplam yatırım maliyeti 2.500.000TL'dir. 
Benzer şekilde özel ilkokul/ortaokul/liselerin yatırım maliyetleri Milli Eğitim Bakanlığı Standartlar Yönergesi’ne göre hesaplanacak olursa, ilkokul, ortaokul ve liselerde bulunması gereken bölümler dikkate alındığında bir ilkokulda yaklaşık 25-30 birim olacaktır. Böyle bir binanın yaklaşık inşaat maliyeti 5-6 milyon TLyi bulmaktadır. Ortalama bir hesapla yukarıda belirtilen özelliklerdeki gibi bir okulun yapımında kullanılacak bahçe alanı ayrılabilecek bir arsa için en az 5 milyon TLyi gerekecektir. Bu durumda 20-30 derslikli bir okulun tüm tefrişi için harcanacak rakam asgari 1,2 milyon TL'dir. Eğer okul binasina büyük bir konferans salonu yapılırsa bu rakam 2 milyonu bulabilmektedir. Ülkemizde okul büyüklüğüne ve yerine göre değişmekle birlikte bir özel okulun yatırım maliyeti yaklaşık olarak 10-13 milyon TL civarında olacaktır.

Özel okulların yaptıkları eğitim yatırımlarının değerleri kurumdan kuruma farklılık göstermektedir. Ortalama yatırım değerinin çok altında yatırım yapmış olarak eğitim hizmeti sunan özel okullar olduğu gibi sadece arsa ve bina maliyeti bakımından ortalamanın çok üstünde olan özel okullar da mevcuttur. Mevcut durumda faaliyetini devam etmekte olan özel okulların tahmini olarak 100 tanesinin yatırım değerinin 50 Milyon \$ civarında olduğu tahmin edilmektedir (TOBB, 2014).

Hesaplamalar "ortalama ve yaklaşık" değerler baz alınarak yapılmıştır. Burada güdülen amaç genel bir çerçeve sunabilmektir. Daha az büyüklükte yatırımlarla hizmet vermekte olan özel okullar olabileceği gibi, Türkiye’nin en güzel merkezi yerlerinde hizmet veren ve sadece arsa ve binaları 700-800 milyon TL değerin üzerinde olduğu tahmin edilen özel okullar da bulunmaktadır.

Özel okulların yapmış oldukları yatırım değerleri dikkate alındığında ülke ekonomisine önemli katkıda bulundukları söylenebilir. Devletin, özel sektörü eğitim hizmetleri verme konusunda teşvik etmesi kamunun üzerinde bulunan mali yükü azaltmaktadır. Devlet tarafından özel okul sektörüne yönelik yapılan teşviklerin bütçeyi azaltan kayıplarmış gibi düşünülmesi hata olup esasında devlet için daha çok vergi geliri ve istihdamı arttırması söz konusudur. Kamuoyunun bu konuda bilinçlendirilmesi ve devlet bürokrasisinin bu bilinç ile hareket etmesi ve özel okul yatırımlarının teşviklerle özendirilmesi sağlanmalıdır (TÖDER, 2015).

Rekabetin şiddetlenmesi nedeniyle özel okullar rakiplerini dikkate alıp çeşitli stratejiler belirleyip performanslarını yükselterek kendi alanlarında en başarılı olmaya çalışmaktadırlar. Özel okulların kullandıkları önemli stratejilerden biri de ülke genelindeki diğer il ve ilçe merkezlerinde yeni şubeler açarak müşteri potansiyelini arttırmak istemeleridir. Yeni şubeler açmak belirli kriterleri ve alternatifleri göz önünde bulundurmayı ve rasyonel kararlar almayı gerektirmektedir. Hem fazla seçeneğin olması hem de özel okulların gerçekleştirmek istedikleri politikalarından dolayı yeni açmayı düşündükleri şubeler için kuruluş yerini seçme konusu, karmaşık yapılı bir problemdir. Bu amaçla çalışmada, özel okul yeri seçimi için rasyonel ve analitik bir yöntem sunmak ve karar vericilere kılavuzluk etmeye yönelik olarak Çok Kriterli Karar Verme metotlarından Analitik Hiyerarşi Süreci ve Gri ilişkisel analiz yöntemi kullanılarak karar vericilerin sağlıklı bir seçim yapabilmesi amaçlanmıştır. 


\section{Yöntem}

Günümüz iş yaşamında karar verme yetkisine sahip olan üst düzey yöneticiler, karşılaştıkları problemlere çözümler üretmek ve mevcut alternatifler arasından seçim yapma durumunda kaldıklarında inisiyatif alarak karar vermek zorundadırlar. Ancak böylesi bir durumda birçok seçeneğin ortaya çıkacak olması üst düzey yöneticilerin karar almasını güçleştirmektedir. Karar vericilerin, uzun vadeli sonuçları düşünerek farklı alternatifler arasından çeşitli analiz ve yöntemleri kullanarak tercih yapması, kurumun etkililiğini ve verimliliğini arttıracaktır. Çok Kriterli Karar Verme Metotları, bu analizlerin başarılı bir şekilde uygulanması için geliştirilmiştir. Böyle durumlarda karar vericilerin çok kriterli karar verme yöntemlerini kullanması, karmaşı yapıdaki problemlerin çözümüne olanak sağlayacaktır.

Bir sonuca varabilmek için potansiyel alternatiflerin ve kriterlerin, karar verme problemlerinde daima var olması gerekmektedir (Doumpos ve Zopounidis, 2002). ÇKKV yöntemlerinin temel amacı; alternatifleri karşılaştırabilecek verileri elde ederek, alternatifler için öncelikli ölçütlerin ve kriterlerin belirlenmesidir (Kaya, 2004). Ayrıca ÇKKV yöntemlerinde değişik özelliklerdeki alternatiflerin belirlenen kriterlere göre karar vericiler tarafından değerlendirilerek, sıralanması işlemi uygulanmaktadır (Özden, 2009).

$\mathrm{Bu}$ çalışmada özel öğretim kurumu yatırım yeri seçim problemi ele alınmıştır. Bu amaçla, özel okul kuruluşunu etkileyebilecek 9 ana kriter tespit edilerek ilgili kriterlerle ilgili resmi olarak yayınlanmış istatistiki sayısal değerleri elde edilmiştir. Bu verilere dayanarak Çok Kriterli Karar Verme Yöntemleri kullanılarak yapılan çalışmanın ilk adımında özel bir eğitim kurumu açmak isteyen yatırımcılara yönelik olarak öncelikle aradığı kriterler belirlenmiş ve bu kriterler baz alınarak yatırım yapılabilirlik açısından Türkiye'deki 81 il önceliklendirilmiştir. Çalışmada kullanılan yöntem ve elde edilen sonuçlardan yararlanılarak özel okul yatırımları için doğru kararların alınması sağlanarak oluşabilecek kayıp ve zararların önlenmesi amaçlanmıştır.

\section{Analitik hiyerarşi süreci}

Analitik Hiyerarşi Süreci (AHS) Thomas L. Saaty (1980) tarafından geliştirilmiş çok ölçütlü problemlerin yapılandırılması, ölçülmesi ve sentezine yönelik bir metodolojidir. AHS bir çok probleme uygulanabilen bir yöntemdir ve özellikle de bir çok kriterin olduğu kompleks durumlarda alternatifler arasından seçim yapma problemlerine uygulanmaktadır (Saaty, 1980; Forman ve Gass, 2001). Asıl çıkış amacı karar vericilerin kompleks kararları verebilmesi için basit bir sistematik yolun geliştirilmesidir İnsan çok sayıda ve birbirleri ile ilişkili öğeler seti ile karşılaştığında, bunların ancak bir kısmını kontrol altında tutabileceği anlaşıldığında çoğunlukla içgüdüsel olarak söz konusu öğeler, belirli bir takım özelliklere sahip olup olmamalarına bağlı olarak, belirli bir takım ortak özelliklere sahip olup olmamalarına bağlı olarak, gruplar halinde birleştirilmeye çalışılır. Analitik hiyerarşi süreçlerinin de temelde gerçekleştirmeyi amaçladığı budur (Kahraman, 1995). Sürecin ilk adımı, karar verme probleminin olabildiğince ayrıntılı olarak ortaya konması ve daha sonra hiyerarşi olarak adlandırılan ve her biri bir dizi öğeden oluşan katmanlar halinde incelenmesidir. Bundan sonra yapılacak olan işlem, hiyerarşinin en alt seviyesindeki öğelerin, en üst düzeyde bulunan ve amacı ortaya koyan öğe üzerindeki göreli 
etkilerinin saptanmasıdır. Bunun belirlenmesi ise karar verme probleminin her hiyerarşik düzeyi için bir dizi ikili karşılaştırma ve göreli ağıllıkların bulunmasına dayanır (Evren ve Ülengin, 1992).

AHS karar vericinin düşüncelerini baz alarak verilen alternatifler için oran skalası üzerinde göreceli önceliklerinin sayısallaştırılmasını amaçlayan ve karar vericinin değerlendirmelerinin önemini ve karar verme sürecinde alternatiflerin karşılaştırılmalarındaki tutarlılı̆̆ 1 dikkate alan bir yöntemdir (Al-Bahar, 2001). Bu yaklaşımın gücü somut ve soyut faktörleri sistematik bir şekilde organize etmesi ve karar verme problemlerine yapılandırılmış ve basit bir çözüm sağlamasıdır (Saaty, 1980, 1990).

AHS’nin uygulama alanları oldukça fazladır ve geniş bir çerçevede yayılmıştır. Bu uygulamaları kısaca özetlenecek olursak; ürün seçimi, tedarikçi seçimi, proje seçimi, organizasyon yapısının seçimi, fabrika yeri seçimi, teknoloji seçimi (birden fazla kriterin bulunduğu durumlarda alternatifler arasından bir tanesinin seçildiği seçim problemleri), performans değerlendirmesi, personel değerlendirmesi, proje değerlendirilmesi (önceliklendirme ve değerlendirme problemleri), kaynak tahsis problemleri, kıyaslama problemleri, kalite yönetimi ve stratejik planlamadir.

AHS yönteminin adımları genel hatlarıyla kısaca aşağıdaki gibi özetlenebilir (Saaty, 1980; 1990);

- Problemin tanımlanması ve amacın belirlenmesi

- Hiyerarşinin oluşturulması ve en üstten (karar vericinin bakış açısından amaç) ara düzeylere (takibindeki düzeylerin bağlı olduğu ölçütlere) daha sonra genellikle alternatiflerin listesini içeren en düşük düzeye kadar yapılandırılması

- Hangi unsurun diğerine daha baskın olduğunu gösterme açısından, Tablo 5’te gösterilen ikili karşılaştırma ölçeği kullanılarak, her seviye için ve daha düşük seviyelerdeki elemanlar için de birer tane ikili karşılaştırma matrisleri $(\mathrm{n} \times \mathrm{n}$ boyutlu) setinin oluşturulması

- Ölçütlerin ağırlıklarını ve öz vektörleri ağırlıklandırılmak için hiyerarşik sentez kullanılması ve hiyerarşinin bir sonraki alt seviyesindekilere karşlık gelen tüm ağırlıklı öz vektörlerin elemanlarının toplanması

- İkili karşılaştırmalar yapıldıktan sonra öznel algıların tutarlılığını ve göreceli ağırlıkların doğruluğunu sağlamak amacıyla tutarlılık indeksi (CI) ve Tutarlılık oranı (CR) olmak üzere iki katsayı kullanılarak tutarlılık indeksinin (CI) hesaplanması (Güvenilir ve gerçekçi sonuçlar için tutarlılık oranının (CR) \% 10’u aşmaması gerekmektedir) 
Tablo 5

AHP'de Kullanılan İili Karşılaştırma Skalası (Saaty, 2005)

\begin{tabular}{lll}
\hline $\begin{array}{l}\text { Önem } \\
\text { Derecesi }\end{array}$ & Tanım & Açıklama \\
\hline 1 & Eşit Derecede Önemli & Faktörlerin ikisi de eşit önem derecesine sahiptir. \\
\hline 3 & Orta Derecede Önemli & $\begin{array}{l}\text { Tecrübelere ve yargılara göre bir faktör diğerine göre biraz daha } \\
\text { önemlidir. }\end{array}$ \\
\hline 5 & Kuvvetli Derecede Önemli & Bir faktör diğerine göre daha kuvvetli derecede önemlidir. \\
\hline 7 & Çok Kuvvetli Derecede Önemli & Bir faktör diğerine göre çok yüksek derecede kuvvetle daha önemlidir. \\
\hline $2,4,6,8$ & Son Derece Önemli & Bir faktör diğerine göre mutlak derecede önemlidir. \\
\hline $\begin{array}{l}\text { Karşı̆llklı Değerler } \\
\text { Değerler }\end{array}$ & $\begin{array}{l}\text { i,j ile karşllaştırıllırken bir değer }(x) \text { atanmış ise: } j, i \text { ile karşılaştırılırken atanacak değer }(1 / x) \\
\text { olacaktır. }\end{array}$ \\
\hline
\end{tabular}

\section{Gri Iilişkisel Analiz (GiA)}

Deng tarafından 1982 yılında önerilen gri sistem teorisi, bulanık küme (Zadeh, 1965) teorisine benzer bir teorisidir. Bu teoriye göre, örneklemin boyutunun küçük olduğu ve belirsizlik içerdiği durumlarda, gri sistem yaklaşımıyla sistemin davranışı tespit edilemeye çalışılır. Gri sistem teorisi, veri işleme, modelleme ve tahmin gibi alanlarda, ayrıca kontrol ve karar verme alanlarında kullanılmaktadır (Kuo vd., 2008).

$\mathrm{Bu}$ yöntemde, bir referans serisi oluşturularak alternatiflerin mutlak farkları alınır. Daha sonra gri ilişkisel katsayılar ve dereceler hesaplanarak en iyi değeri veren alternatif seçilir. Temel bakış açısı bir alternatifin ne derecede referans serisine yakın olduğunu hesaplayabilmektir. ÇKKV yöntemlerinden olan gri ilişkisel analiz, genel olarak tek başına kullanılmaktan ziyade diğer tekniklerle birleştirilerek kullanılmaktadır (Ozcan ve Tüysüz, 2016). Aşağıda bu yöntemin adımları kısaca açıklanmıştır (Chang vd., 2003).

Adım 1: İlk olarak problemin kriterleri, kriter ağırlıkları ve alternatifleri belirlenerek karar matrisi oluşturulur. Bu karar matrisindeki kriterlerin hangisinin maliyet veya hangisinin fayda kriterleri olduğu belirlenir. Daha sonra her bir kriter sütunundaki en iyi değerler temel alınarak bir referans serisi oluşturulur. İlerleyen adımlarda hangi alternatifin bu referans serisine daha yakın olduğu tespit edilecektir.

Adım 2: Bir önceki adımda karar matrisinde, her bir alternatifin her bir kriter için aldığ1 değerlerin birimleri farklı olduğundan normalizasyona referans serisi de dahil olmak üzeregerek duyulur. Fakat normalizasyon, kriterin maliyet, fayda veya nominal kriteri olmasına göre değişir.

Adım 3: Karar matrisi normalize edildikten sonra gri ilişkisel katsayı matrisi oluşturulur. $\mathrm{Bu}$ matris oluşturulurken ilk adım her bir normalize edilmiş karar matrisi biriminin, ilgili kriterdeki referans değerinden çıkarılıp mutlak değerinin alınmasıdır. 
Adım 4: Son adımda gri ilişkisel dereceler hesaplanarak, hangi alternatifin referans serisine daha yakın olduğu ve buna bağlı olarak hangi alternatifin seçilmesi gerektiği belirlenir. Her bir alternatif için hesaplanan gri ilişkisel derece değerlerinden en büyüğü seçilerek karar problemi sonuçlandırılır.

Şekil 1'de çalışmada önerilen karar modelinin genel çerçevesi görülmektedir.

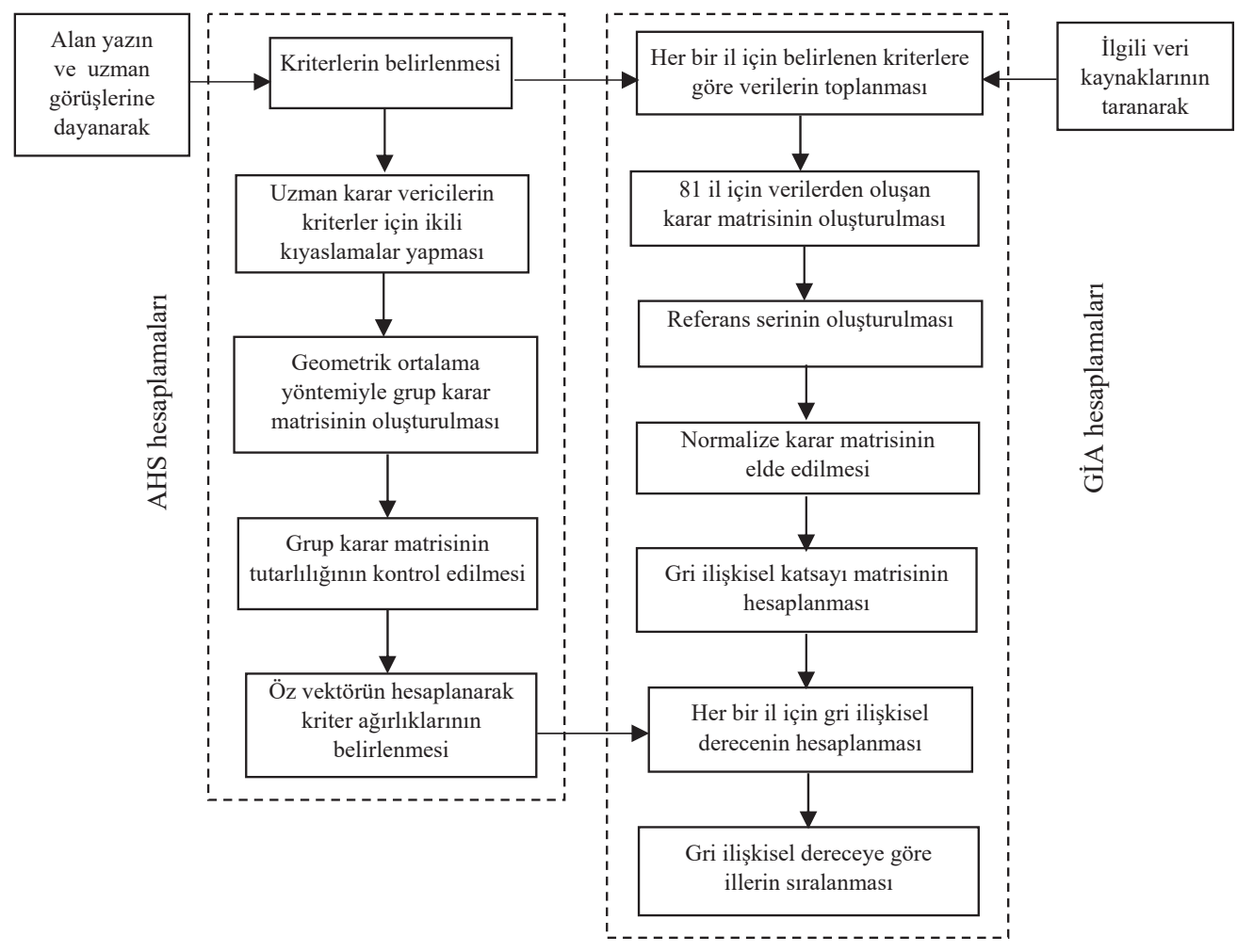

Şekil I. Özel okul yatırımları için önerilen karar modeli

\section{Bulgular}

Bu çalışmada özel öğretim kurumu yatırım yeri seçimi problemi ele alınmıştır. Bu amaçla, özel okul kuruluşunu etkileyebilecek 9 ana kriter tespit edilerek ilgili kriterlerle ilgili resmi olarak yayınlanmış istatistiki sayısal değerleri elde edilmiştir. Bu verilere dayanarak ÇKKV yöntemleri kullanılarak yapılan çalışmanın ilk adımında özel bir eğitim kurumu açmak isteyen yatırımcılara yönelik olarak öncelikle aradığı kriterler belirlenmiş ve bu kriterler baz alınarak yatırım yapılabilirlik açısından Türkiye’deki 81 il önceliklendirilmiştir. 
Uygulamada kullanılan ÇKKV metodoloji AHS ile bütünleştirilmiş GİA yaklaşımına dayanmaktadır. AHS özel okul yatırımlarında kullanılacak olan gösterge veya kriterlerin uzman görüşüne dayalı olarak değerlendirilip öncelik derecelerinin belirlenmesi için kullanılmıştır. GİA ise Türkiye'deki 81 ilin her birinin belirlenen kriterlere göre ilgili kaynaklardan elde edilen objektif veriler kullanılarak sıralanması amacıyla kullanılmıştır. Bu yönüyle sunulan metodoloji hem objektif verilerin kullanılması hem de uzman görüşüne dayalı bir karar modeli sunması açısından önem arz etmektedir.

Bu amaçla, ilk olarak, özel okul yatırım kararında belirleyici olacağı düşünülen kriterler, ilgili alanyazın taranarak (Wachtel, 1976; Hanushek, 1996; Peetsma, 2000; Köktaş, 2009; Işık, 2009; Çıngı vd., 2013) tespit edilmiş ve uzman değerlendirmesi sonucunda elde edilen kriterler Tablo 6 'da verilmiştir.

Tablo 6

Özel Okul Yatırımları için Kullanılan Değerlendirme Kriterleri

Kriter (Her bir il için)

Eğitim endeksi sırası (K1)

Genel yaşam endeksi sırası (K2)

Özel okulların tüm okullar içindeki oranı (K3)

Özel okullarda okuyan öğrencilerin oranı (K4)

3-17 yaş arası nüfusun toplan nüfus içindeki payı (K5)

Yaşa (0-19) göre (alınan göç/verilen göç) oranı (K6)

Derslik başına düşen ortalama öğrenci sayısı (K7)

Hane halkı eğitim harcaması (il/Türkiye) oranı (K8)

Kişi başı ortalama mevduat miktarı (K9)

Tablo 6'da gösterilen kriterlere ait veriler 2015-2016 Milli Eğitim İstatistikleri, 2016 TUİK istatistikleri, Sabancı Üniversitesi Eğitim Reformu Girişimi (ERG) 2015-2016 raporu, 2014 Türkiye Eğitim Meclisi Sektör Raporu ve 2016 Türkiye Bankalar Birliği istatistiki raporlarından alınmıştır.

Çalışmada kullanılan 9 kriter, eğitim yönetimi ve denetimi alanında en az lisans üstü derecesine sahip akademisyenler ve de özel okul sektöründe en az 10 yıl deneyimli yöneticilerden oluşan 14 uzman karar verici tarafından AHS yöntemiyle değerlendirilmiştir. Tablo 7 AHS yöntemine ait örnek bir karşılaştırma matrisini göstermektedir. 
Marmara Üniversitesi Atatürk Eğitim Fakültesi Eğitim Bilimleri Dergisi • Journal of Educational Sciences YIl: Ocak $2017 \cdot$ Cilt-Sayı $45 \cdot$ ISSN: I300-8889 • ss. 93-II 4

Tablo 7

AHS Yöntemine Ait Örnek Bir Karşılaştırma Matrisi

\begin{tabular}{|c|c|c|c|c|c|c|c|c|c|}
\hline $\begin{array}{c}\text { İl Bazında Özel } \\
\text { Okul Yatırım1 }\end{array}$ & K1 & K2 & K3 & K4 & K5 & K6 & K7 & K8 & K9 \\
\hline K1 & 1 & $1 / 3$ & $1 / 3$ & 4 & 5 & 4 & 5 & $1 / 4$ & $1 / 3$ \\
\hline K2 & 3 & 1 & 5 & 5 & 5 & 2 & 3 & $1 / 4$ & $1 / 3$ \\
\hline K3 & 3 & $1 / 5$ & 1 & $1 / 5$ & $1 / 3$ & 3 & $1 / 2$ & $1 / 6$ & 0.2 \\
\hline K4 & $1 / 4$ & $1 / 5$ & 5 & 1 & 4 & 4 & 5 & $1 / 4$ & $2 / 4$ \\
\hline K5 & $1 / 5$ & $1 / 5$ & 3 & $1 / 4$ & 1 & 4 & 3 & $1 / 4$ & $1 / 3$ \\
\hline K6 & $1 / 4$ & $1 / 2$ & $1 / 3$ & $1 / 4$ & $1 / 4$ & 1 & 4 & $1 / 4$ & $2 / 4$ \\
\hline K7 & $1 / 5$ & $1 / 3$ & 2 & $1 / 5$ & $1 / 3$ & $1 / 4$ & 1 & $1 / 5$ & $2 / 4$ \\
\hline K8 & 4 & 4 & 6 & 4 & 4 & 4 & 5 & 1 & $1 / 2$ \\
\hline K9 & 3 & 3 & 5 & 4 & 3 & 4 & 4 & 2 & 1 \\
\hline
\end{tabular}

Karşılaştırma matrisinde yer alan ikili kıyaslamalar Tablo 1'de verilen skala kullanılarak yapılmıştır. Tablo 7’deki 1. satır 2. sütun elemanını açıklayacak olursak; İl Bazında Özel Okul Yatırımı açısından K2, K1'den “Orta Derecede daha Önemli” anlamına gelmektedir. Aynı şekilde 1. satır 4. sütun elemanını açıklayacak olursak; İl Bazında Özel Okul Yatırımı açısından K1, K4'den "Orta-Kuvvetli Arası Derecede daha Önemli” anlamına gelmektedir. 14 uzman karar vericinin her birinin karşılaştırma matrislerini oluşturmasından sonra bunların geometrik ortalaması alınarak grup karşılaştırma matrisi Tablo 8'deki şekilde elde edilmiştir.

Tablo 8

AHS Yöntemine Ait Grup Karşılaştırma Matrisi

\begin{tabular}{|c|c|c|c|c|c|c|c|c|c|}
\hline $\begin{array}{c}\text { İl Bazında Özel } \\
\text { Okul Yatırım1 }\end{array}$ & K1 & K2 & K3 & K4 & K5 & K6 & K7 & K8 & K9 \\
\hline K1 & 1,000 & 0,730 & 1,209 & 2,381 & 2,377 & 1,690 & 2,370 & 1,054 & 0,942 \\
\hline K2 & 1,370 & 1,000 & 2,408 & 2,786 & 2,958 & 2,129 & 2,974 & 1,485 & 1,265 \\
\hline K3 & 0,827 & 0,415 & 1,000 & 1,142 & 1,396 & 1,669 & 0,775 & 0,705 & 0,579 \\
\hline K4 & 0,420 & 0,359 & 0,876 & 1,000 & 2,318 & 1,385 & 1,179 & 0,882 & 0,719 \\
\hline K5 & 0,421 & 0,338 & 0,716 & 0,431 & 1,000 & 1,896 & 1,224 & 0,716 & 0,786 \\
\hline K6 & 0,592 & 0,470 & 0,599 & 0,722 & 0,527 & 1,000 & 1,224 & 0,822 & 0,723 \\
\hline K7 & 0,422 & 0,336 & 1,290 & 0,848 & 0,817 & 0,817 & 1,000 & 1,235 & 0,964 \\
\hline K8 & 0,949 & 0,673 & 1,419 & 1,134 & 1,396 & 1,217 & 0,810 & 1,000 & 1,357 \\
\hline K9 & 1,061 & 0,790 & 1,727 & 1,390 & 1,272 & 1,383 & 1,037 & 0,737 & 1,000 \\
\hline
\end{tabular}

Tablo 8'deki verilen grup karşılaştırma matrisinin CR oranı \% 2,7 olarak elde edilmiştir. Bu da grup matrisinin tutarlılığının \%97,3 olduğunu göstermektedir. Öz vektör hesabıyla Tablo 9'da özel okul yatırımları için kullanılan değerlendirme kriterlerinin elde edilen ağırlıkları yer almaktadır. 
Tablo 9

Özel Okul Yatırımları Kriterlerinin Elde Edilen Ağılıkları

\begin{tabular}{ll}
\hline Kriter & Ağıllık \\
\hline Eğitim endeksi sırası (K1) & 0,146 \\
\hline Genel yaşam endeksi sırası (K2) & 0,197 \\
\hline Özel okulların tüm okullar içindeki oranı (K3) & 0,091 \\
\hline Özel okullarda okuyan öğrencilerin oranı (K4) & 0,094 \\
\hline 3-17 yaş arası nüfusun toplan nüfus içindeki payı (K5) & 0,079 \\
\hline Yaşa (0-19) göre (alınan göç/verilen göç) oranı (K6) & 0,076 \\
\hline Derslik başına düşen ortalama öğrenci sayısı (K7) & 0,086 \\
\hline Hane halkı eğitim harcaması (il/Türkiye) oranı (K8) & 0,113 \\
\hline Kişi başı ortalama mevduat miktarı (K9) & 0,118 \\
\hline
\end{tabular}

Tablo 9'daki sonuçlara göre 14 uzman karar vericiye göre en önemli kriter \%19,7 ağırlık ile "Genel yaşam endeksi sırası (K2)" iken en az önemli kriter ise \% 7,6 ağırlık ile "Yaşa (0-19) göre (alınan göç/verilen göç) oranı (K6)" olmuştur. "Genel yaşam endeksi sırası (K2)” ve "Eğitim endeksi sırası (K1)” kriterleri diğerleri ile kıyaslandığında tüm kriter ağırlıkları içerisinde yaklaşık \%35’lik toplam ağırlık veya önem derecesine sahiptirler.

Uzman görüşlerine dayanarak kriter ağırlıkları veya önem dereceleri belirlendikten sonra GİA yöntemi ile 81 ilin özel okul yatırım yapılabilirliği açısından önceliklendirilmesi aşağıdaki şekilde yapılmıştır.

GİA hesaplamalarında kullanılan Türkiye'deki 81 ile ait karar matrisi Ek A Tablo Al'de verilmiştir. Bu tabloda belirtilen kriter tiplerine göre her bir kriter sütunundaki en iyi değerler temel alınarak elde edilen referans serisi Tablo 10'daki gibi elde edilmiştir.

Tablo 10

GíA için Referans Seri

\begin{tabular}{cccccccccc}
\hline Kriter & K1 & K2 & K3 & K4 & K5 & K6 & K7 & K8 & K9 \\
\hline Referans Seri & 1,000 & 1,000 & 0,062 & 0,070 & 1,600 & 1,750 & 1,462 & 1,300 & $148.377,365$ \\
\hline
\end{tabular}

Sonraki adımda, kriter tipine göre her bir şehir için normalize değerler hesaplanmıştır. K1, K2, K3 ve K4 kriterleri için maliyet normalizasyonu ve de K5, K6, K7, K8 ve K9 kriterleri için de fayda normalizasyonu uygulanmıştır. Normalize karar matrisi hesaplandıktan sonra gri ilişkisel katsayı matrisi oluşturulmuştur. Son olarak da Tablo 11'de verilen gri ilişkisel dereceler ve de 81 ilin özel okul yatırımı açısından öncelik sıraları elde edilmiştir. 
Marmara Üniversitesi Atatürk Eğitim Fakültesi Eğitim Bilimleri Dergisi • Journal of Educational Sciences Yıl: Ocak 2017 • Cilt-Sayı $45 \cdot$ ISSN: I300-8889 • ss. 93-II4

\section{Tablo 11}

\section{Illin Özel Okul Yatırımı Açısından Öncelik Sıralaması}

\begin{tabular}{|c|c|c|c|c|c|}
\hline \multicolumn{3}{|c|}{ Gri İlişkisel } & \multicolumn{3}{|c|}{ Gri İlişkisel } \\
\hline İl & Derece & Öncelik Sırası & İl & Derece & Öncelik Sırası \\
\hline Isparta & 0,6801 & 1 & Gümüşhane & 0,5256 & 42 \\
\hline İstanbul & 0,6680 & 2 & Ağr1 & 0,5253 & 43 \\
\hline Bolu & 0,6659 & 3 & Mersin & 0,5250 & 44 \\
\hline Karabük & 0,6332 & 4 & Nevşehir & 0,5204 & 45 \\
\hline Eskişehir & 0,6098 & 5 & Tunceli & 0,5187 & 46 \\
\hline Balıkesir & 0,6061 & 6 & Gaziantep & 0,5183 & 47 \\
\hline Çanakkale & 0,6060 & 7 & Diyarbakır & 0,5146 & 48 \\
\hline Kütahya & 0,6054 & 8 & Batman & 0,5139 & 49 \\
\hline Kurşehir & 0,6052 & 9 & Bitlis & 0,5139 & 50 \\
\hline Yalova & 0,6011 & 10 & Antalya & 0,5136 & 51 \\
\hline Sakarya & 0,5981 & 11 & Bayburt & 0,5129 & 52 \\
\hline Uşak & 0,5945 & 12 & Muş & 0,5126 & 53 \\
\hline Amasya & 0,5921 & 13 & Adryaman & 0,5111 & 54 \\
\hline Artvin & 0,5915 & 14 & Bingöl & 0,5082 & 55 \\
\hline Bilecik & 0,5896 & 15 & Kahramanmaraş & 0,5072 & 56 \\
\hline Giresun & 0,5894 & 16 & Van & 0,5061 & 57 \\
\hline Burdur & 0,5879 & 17 & Kayseri & 0,5059 & 58 \\
\hline Afyonkarahisar & 0,5716 & 18 & Tekirdağ & 0,5057 & 59 \\
\hline Denizli & 0,5668 & 19 & Elazı̆̆ & 0,5056 & 60 \\
\hline Ankara & 0,5651 & 20 & Malatya & 0,5045 & 61 \\
\hline Trabzon & 0,5638 & 21 & Niğde & 0,5036 & 62 \\
\hline Tokat & 0,5635 & 22 & Manisa & 0,5015 & 63 \\
\hline Kastamonu & 0,5616 & 23 & Sivas & 0,5001 & 64 \\
\hline Sinop & 0,5570 & 24 & Aydın & 0,4993 & 65 \\
\hline Rize & 0,5564 & 25 & Muğla & 0,4944 & 66 \\
\hline Konya & 0,5548 & 26 & Adana & 0,4934 & 67 \\
\hline Kırklareli & 0,5543 & 27 & Yozgat & 0,4919 & 68 \\
\hline Bursa & 0,5523 & 28 & Kilis & 0,4890 & 69 \\
\hline Karaman & 0,5485 & 29 & Çorum & 0,4870 & 70 \\
\hline Siirt & 0,5458 & 30 & Hatay & 0,4836 & 71 \\
\hline Kırıkkale & 0,5456 & 31 & Aksaray & 0,4834 & 72 \\
\hline Şırnak & 0,5406 & 32 & Erzurum & 0,4824 & 73 \\
\hline Mardin & 0,5382 & 33 & Iğdır & 0,4820 & 74 \\
\hline Hakkâri & 0,5379 & 34 & Düzce & 0,4812 & 75 \\
\hline Kocaeli & 0,5366 & 35 & Bartın & 0,4806 & 76 \\
\hline Erzincan & 0,5365 & 36 & Zonguldak & 0,4783 & 77 \\
\hline İzmir & 0,5338 & 37 & Osmaniye & 0,4737 & 78 \\
\hline Edirne & 0,5335 & 38 & Ordu & 0,4723 & 79 \\
\hline Şanlıurfa & 0,5327 & 39 & Kars & 0,4712 & 80 \\
\hline Samsun & 0,5303 & 40 & Ardahan & 0,4637 & 81 \\
\hline Çankırı & 0,5272 & 41 & & & \\
\hline
\end{tabular}


Tablo 11'deki sonuçlara göre, 14 uzman karar vericinin görüşleri sonucu elde edilen kriter ağırlıkları ve de 81 il için her bir kritere ait verilere dayanarak Isparta özel okul yatırımı açısından en öncelikli il iken Ardahan en düşük önceliğe sahip il olarak elde edilmiştir. Isparta'dan sonra sırasıyla İstanbul, Bolu, Karabük ve Eskişehir illeri özel okul yatırımı açısından en öncelikli 5 il iken, Zonguldak, Osmaniye, Ordu, Kars ve Ardahan en düşük önceliğe sahip iller olmuşlardır. Sıralamada ilk 15'de Marmara Bölgesinden 5 il (İstanbul, Balıkesir, Çanakkale, Yalova ve Bilecik illeri) yer almaktadır. Bununla beraber, sıralamada Marmara, Batı Karadeniz ve İç Anadolu bölgelerinde yer alan iller ilk 20 sıralamasında yer almaktadırlar.

\section{Sonuç ve öneriler}

Ülkemizde eğitim sektörü sürekli bir şekilde gelişmekte ve eğitim yatırımları da hızlı bir şekilde artmaktadır. Mevcut durumda özel okulların sayısı, devletin de bu okulları teşvik etmesiyle birlikte her geçen gün artmaktadır. Özel okul yatırımları açısından bakıldı̆̆ında gerek seçeneklerin fazla oluşu gerekse özel okulların kendi uyguladıkları politikaları nedeniyle okul yeri seçimi karmaşı yapılı bir sorundur. Bu sebeple bu çalışmada özel öğretim kurumu yatırım yeri seçimi problemi ele alınmıştır ve de özel okul yatırımı yapmak isteyen girişimciler için yatırım yeri seçiminin kolaylaştırılması amacı ile ÇKKV metotlarından AHP ve GİA yöntemleri kullanılarak karar vericilerin bilimsel verilere dayalı olarak rasyonel bir seçim yapabilmesi amaçlanmıştır.

İlk olarak, ilgili alan yazın taraması ve uzman görüşleri dikkate alınarak özel okul yatırımları konusunda öncelikle temel alınacak 9 ana kriter tespit edilmiştir. AHS yöntemi ile özel okul yatırımlarında kullanılacak olan kriterlerin uzman görüşüne dayalı olarak değerlendirilip her birinin önem seviyesi belirlenmiştir. Kriter ağırlıkları elde edildikten sonra, GİA yöntemi ile Türkiye'deki 81 il belirlenen kriterler ve ağırlıklarına göre MEB, TUİK ve diğer ilgili kaynaklardan elde edilen objektif veriler kullanarak özel okul yatırım yapılabilirliği açısından sıralanmıştır. Uygulamada elde edilen sonuçlar ve kullanılan yöntem özel okul yatırımları için rasyonel ve doğru kararların alınması sağlaması ve de oluşabilecek kayıp ve zararların önlenmesi açısından önemlidir. Bununla beraber uygulamada elde edilen sonuçlar, özellikle kriter ağırlıklarının belirlenmesinde, uzman görüşüne dayandığından ötürü uzmanlar veya karar vericiler değiştikçe kriter ağırlıkları da değişeceğinden dolayı illerin sıralaması da değişebilecektir.

Bu çalışmada önerilen metodoloji hem objektif verilerin kullanılması hem de uzman görüşüne dayalı bir karar modeli sunması açısından önem arz etmektedir. Buna ilaveten önerilen metodoloji yeni kriterlerin eklenip çıkarılmasına ve de istenildiği kadar uzman veya karar vericinin sürece katılmasına imkan vermesinden ötürü oldukça esnek bir yaklaşımdır. Bu sebeple de, yalnızca özel okul yatırımları için değil, uzman görüşü ve objektif verilere dayalı ÇKKV problemlerinde de uygulanabilirdir. İleriki çalışmalarda, bu kriter setinin daha da genişletilmesi veya geliştirilmesi ya da sadece özel eğitim kurumları yatırımları değil, diğer devlet ve özel sektör yatırımlarında da bu önerilen yaklaşımın kullanılması düşünülebilir. Bir diğer gelecek çalışmalar önerisi olarak da çalışmada sunulan yöntemin bulanık kümeler teorisi ile birlikte ele alınarak uygulanması da düşünülebilir. 


\section{Kaynaklar}

Ağaya, S. (2012). Özel öğretim kurumlarında muhasebe ve vergilendirme sistemi: örnek bir uygulama. (Yayınlanmamış Lisans tezi). Erciyes Üniversitesi, İstanbul.

Başkaya, B. (2006). İstanbul ili özel okullarındaki halkla ilişkiler uygulamaları. (Yayınlanmamış Lisans tezi). Yeditepe Üniversitesi, İstanbul.

Chang, C. L., Tsai, C. H., \& Chen, L. (2003). Applying grey relational analysis to the decathlon evaluation model. Int J Comput Internet Manage, 11(3), 54-62.

Çelik, Y. (2006). Özel okulların Türk eğitim sistemine ekonomik katkılarının değerlendirilmesi. (Yayınlanmamış Lisans tezi). Gazi Üniversitesi, Ankara.

Çıngı, H., Kadılar, C., \& Koçberber, G. (2013) Türkiye’de ilçelere göre kamu ilköğretim ve ortaöğretim okullarındaki ihtiyaçların belirlenmesine yönelik istatistiksel bir yaklaşım. Journal of Education, 28(1), 105-116.

Demirci, K., Taşkın, E., Yuca, U. (2006). Öğrenen örgüt/pazarlama yönelimli öğrenen okul boyutlarının analizi: Kütahya ili özel eğitim kurumları uygulaması. Akademik Bakış, 9.

Doumpos, M., Zopounidis, C. (2002). "Multicriteria Classification and Sorting Methods: A Literature Review," European Journal of Operational Research, 138, 229-246.

Eğitim Reformu Girişimi (ERG), (2013). Eğitim İzleme Raporu 2015-2016, Sabancı Üniversitesi, http:// www.egitimreformugirisimi.org/sites/www.egitimreformugirisimi.org/files/EIR2015-16.10.02.17. web.pdf adresinden 05.09.2016 tarihinde edinilmiştir.

Ekonomi Bakanlığı. (2012). 1 sayılı Yatırımlarda Devlet Yardımları Hakkında Kararın Uygulanmasına İlişkin Tebliğ. Ankara: Resmi Gazete sayıs1: 28329. http://www.resmigazete.gov.tr/ eskiler/2012/06/20120620-8.htm. Erişim Tarihi: 02.20.2017

Eurydice, E. A. C. E. A. (2012). Key data on education in Europe 2012. Brussels: Eurydice.

Evren, R., Ülengin, F., 1992. Yönetimde karar verme. İTÜ Yayınları, No.1478.

Forman, E. H., \& Gass, S. I. (2001). The analytic hierarchy process-an exposition. Operations research, 49(4), 469-486.

Hanushek, E. A. (1996). Measuring investment in education. The Journal of Economic Perspectives, 10(4), 9-30.

Işık, Ş. (2009). Türkiye’de eğitim amaçlı göçler. Coğrafi Bilimler Dergisi, 7(1), 27-37.

Ju-Long, D. (1982). Control problems of grey systems. Systems \& Control Letters, 1(5), 288-294.

Kahraman, C., (1995). İleri imalat teknolojilerinin ekonomik analizi ve esneklik faktörünün sayısallaştırılmasına bulanık kümeler yaklaşımı. İTÜ Fen Bilimleri Enstitüsü Doktora Tezi.

Kandemir, Y. (2015). Devlet okulu öğretmenlerinin özel okullara ilişkin tutumlarının incelenmesi. (Yayınlanmamış Y. Lisans tezi). Yeditepe Üniversitesi, İstanbul.

Kaya, Y. (2004). "Çok Amaçlı Karar Verme Yöntemlerinden TOPSIS ve ELECTRE Yöntemlerinin Karşılaştırılması,” Havacılık ve Uzay Teknolojileri Enstitüsü, İstanbul, Haziran. Erişim: http:// www.hho.edu.tr

Köktaş, A. M. (2009). Türkiye’de Hanehalkı Eğitim Harcamaların Analizi, Ankara Üniversitesi Sosyal Blimler Enstitüsü, Yüksek Lisans Tezi.

Kuo, Y., Yang, T., \& Huang, G. W. (2008). The use of grey relational analysis in solving multiple attribute decision-making problems. Computers \& Industrial Engineering, 55(1), 80-93.

Millî Eğitim Bakanlığı (2007). Özel Öğretim Kurumları Kanunu (2007). http://www.mevzuat.gov. tr/Metin1.Aspx?MevzuatKod=1.5.5580\&MevzuatIliski=0\&sourceXmlSearch $=\&$ Tur $=$ 1\&Tertip $=5 \& \mathrm{No}=5580$. Erişim Tarihi: 02.20.2017. 
Millı̂ Eğitim Bakanlı̆̆ı Özel Öğretim Kurumları Yönetmeliği. (2012). Resmi Gazete Tarihi: 20.03.2012 Resmi Gazete Sayısı: 28239. http://ookgm.meb.gov.tr/www/yonetmelik/icerik/72. Erişim Tarihi: 02.20.2017.

Millî Eğitim Bakanlığı Özel Öğretim Kurumları Yönetmeliğinde Değişiklik Yapılmasına Dair Yönetmelik. (2014). http://www.resmigazete.gov.tr/eskiler/2016/12/20140705.htm. Erişim Tarihi: 02.20.2017.

Milli Eğitim Bakanlığı, (2016). Milli Eğitim İstatistikleri - Örgün Öğretim. Strateji Geliştirme Başkanlığı. http://sgb.meb.gov.tr/meb_iys_dosyalar/2016_03/18024009_meb_istatistikleri_orgun_ egitim_2015_2016.pdf adresinden 07.10.2016 tarihinde edinilmiştir.

Ozcan, T., \& Tuysuz, F. (2016). Modified grey relational analysis integrated with grey dematel approach for the performance evaluation of retail stores. International Journal of Information Technology \& Decision Making, 15(02), 353-386.

Özden, H. O. (2009). Türkiye'deki Mevduat Bankalarının Performanslarının Çok Kriterli Karar Verme Yöntemleri ile Analizi. Ankara: Detay Yayıncilık.

Peetsma, T. T. (2000). Future time perspective as a predictor of school investment. Scandinavian Journal of Educational Research, 44(2), 177-192.

Saaty Thomas, L. (1980). The analytic Hierarchy process. New York: McGrow-Hill.

Saaty, T. L. (1990). How to make a decision: the analytic hierarchy process. European journal of operational research, 48(1), 9-26.

Saaty, T. L. (2005). Theory and applications of the analytic network process: decision making with benefits, opportunities, costs, and risks. RWS publications.

Saaty, T. L., \& Vargas, L. G. (2012). Models, methods, concepts \& applications of the analytic hierarchy process (Vol. 175). Springer Science \& Business Media.

Subaşı, B., Dinler, A. (2003). Dünya da ve Türkiye’de Özel Okullar. İstanbul: İTO Yayınları

TOBB (2014). Türkiye eğitim Meclisi Sektör Raporu. Türkiye Odalar ve Borsalar Birliği. Ankara, 2014. http:// www.tobb.org.tr/TurkiyeSektorMeclisleri/Sayfalar/SektorRaporlari.php adresinden 05.09.2016 tarihinde edinilmiştir.

Türkiye Bankalar Birliği, (2016). https://www.tbb.org.tr/tr/bankacilik/banka-ve-sektor-bilgileri/istatistikiraporlar/59 adresinden 07.10.2016 tarihinde edinilmiştir.

Türkiye İstatistik Kurumu, (2016). http://www.tuik.gov.tr/UstMenu.do?metod=kategorist adresinden 07.10.2016 tarihinde edinilmiştir.

Türkiye Odalar ve Borsalar Birliği, (2015). Türkiye eğitim meclisi sektör raporu 2014, https://www. tobb.org.tr/Documents/yayinlar/2014/T\%C3\%BCrkiye\%20E\%C4\%9Fitim\%20Meclis\%20 Sekt\%C3\%B6r\%20Raporu\%202014\%20web.pdf adresinden 07.10.2016 tarihinde edinilmiştir.

Uygun, S. (2003). Türkiye’de dünden bugüne özel okullara bir bakış (Gelişim ve etkileri). Ankara University, Journal of Faculty of Educational Sciences, 36(1-2).

Wachtel, P. (1976). The effect on earnings of school and college investment expenditures. The Review of Economics and Statistics, 326-331. 
Ekler A

Tablo A1

Türkiye'deki 8I ilin GiA için karar matrisi

\begin{tabular}{|c|c|c|c|c|c|c|c|c|c|}
\hline Kriter Tipi & Maliyet & Maliyet & Maliyet & Maliyet & Fayda & Fayda & Fayda & Fayda & Fayda \\
\hline İl & K1 & $\mathrm{K} 2$ & K3 & K4 & K5 & K6 & K7 & K8 & K9 \\
\hline Adana & 63 & 61 & 0,715 & 0,692 & 1,060 & 0,770 & 1,202 & 0,910 & 9561,190 \\
\hline Adıyaman & 64 & 69 & 0,240 & 0,271 & 1,230 & 0,630 & 1,025 & 0,820 & 548,247 \\
\hline Afyonkarahisar & 48 & 10 & 0,412 & 0,443 & 0,960 & 1,000 & 0,729 & 0,690 & 1553,438 \\
\hline Ağrn & 79 & 79 & 0,114 & 0,118 & 1,530 & 0,340 & 1,164 & 0,390 & 277,665 \\
\hline Aksaray & 57 & 54 & 0,428 & 0,600 & 1,100 & 0,830 & 0,760 & 0,690 & 720,184 \\
\hline Amasya & 3 & 27 & 0,487 & 0,585 & 0,850 & 0,840 & 0,702 & 0,820 & 659,206 \\
\hline Ankara & 44 & 17 & 2,569 & 1,993 & 0,880 & 1,460 & 1,031 & 1,260 & 39624,081 \\
\hline Antalya & 16 & 44 & 1,433 & 1,246 & 0,930 & 1,340 & 0,944 & 0,690 & 13477,809 \\
\hline Ardahan & 74 & 74 & 0,222 & 0,247 & 1,020 & 0,460 & 0,677 & 0,390 & 176,330 \\
\hline Artvin & 33 & 8 & 0,313 & 0,200 & 0,760 & 0,760 & 0,648 & 0,520 & 490,852 \\
\hline Aydın & 28 & 46 & 0,978 & 1,002 & 0,820 & 1,280 & 0,728 & 0,820 & 5318,698 \\
\hline Balıkesir & 12 & 7 & 0,703 & 0,733 & 0,740 & 1,090 & 0,816 & 0,650 & 5332,640 \\
\hline Bartın & 54 & 38 & 0,621 & 0,801 & 0,770 & 1,070 & 0,583 & 0,690 & 733,336 \\
\hline Batman & 72 & 77 & 0,500 & 0,412 & 1,510 & 0,800 & 1,286 & 0,560 & 436,183 \\
\hline Bayburt & 50 & 47 & 0,330 & 0,462 & 0,950 & 1,560 & 0,604 & 0,470 & 79,506 \\
\hline Bilecik & 25 & 13 & 0,783 & 0,605 & 0,790 & 1,340 & 0,744 & 0,950 & 498,431 \\
\hline Bingöl & 68 & 63 & 0,138 & 0,228 & 1,160 & 0,600 & 0,861 & 0,780 & 216,319 \\
\hline Bitlis & 70 & 68 & 0,137 & 0,112 & 1,460 & 0,540 & 0,931 & 0,210 & 197,688 \\
\hline Bolu & 14 & 3 & 0,571 & 0,240 & 0,780 & 1,290 & 0,945 & 0,820 & 875,589 \\
\hline Burdur & 6 & 43 & 0,284 & 0,256 & 0,790 & 1,310 & 0,620 & 0,690 & 840,280 \\
\hline Bursa & 29 & 19 & 1,382 & 1,289 & 0,910 & 1,240 & 1,092 & 0,950 & 12145,655 \\
\hline Çanakkale & 8 & 24 & 0,500 & 0,535 & 0,660 & 1,650 & 0,780 & 0,650 & 2085,605 \\
\hline Çankırı & 45 & 22 & 0,213 & 0,458 & 0,790 & 0,620 & 0,660 & 0,470 & 364,983 \\
\hline Çorum & 53 & 56 & 0,410 & 0,446 & 0,880 & 0,530 & 0,786 & 0,820 & 1185,478 \\
\hline Denizli & 11 & 26 & 0,958 & 0,865 & 0,880 & 1,300 & 0,829 & 0,820 & 4813,815 \\
\hline Diyarbakır & 73 & 75 & 0,514 & 0,491 & 1,390 & 0,650 & 1,462 & 0,390 & 1648,552 \\
\hline Düzce & 65 & 49 & 0,575 & 0,648 & 0,920 & 0,970 & 0,786 & 0,820 & 657,521 \\
\hline Edirne & 10 & 35 & 0,854 & 0,788 & 0,660 & 1,210 & 0,715 & 0,520 & 1972,299 \\
\hline Elazığ & 40 & 58 & 0,537 & 0,474 & 1,004 & 0,910 & 0,985 & 0,780 & 1069,090 \\
\hline Erzincan & 24 & 34 & 0,355 & 0,475 & 0,860 & 1,210 & 0,606 & 0,470 & 557,591 \\
\hline Erzurum & 62 & 52 & 0,287 & 0,584 & 1,160 & 0,550 & 0,906 & 0,470 & 792,371 \\
\hline Eskişehir & 18 & 15 & 0,925 & 1,021 & 0,760 & 1,750 & 0,926 & 0,950 & 3715,949 \\
\hline Gaziantep & 67 & 60 & 0,695 & 0,628 & 1,320 & 0,850 & 1,365 & 0,820 & 2709,672 \\
\hline Giresun & 7 & 29 & 0,268 & 0,310 & 0,800 & 1,070 & 0,691 & 0,520 & 1295,707 \\
\hline Gümüşhane & 36 & 50 & 0,212 & 0,297 & 0,840 & 1,400 & 0,552 & 0,520 & 194,354 \\
\hline Hakkâri & 81 & 76 & 0,180 & 0,116 & 1,390 & 0,420 & 1,453 & 0,210 & 157,767 \\
\hline Hatay & 51 & 64 & 0,616 & 0,522 & 1,170 & 0,750 & 1,044 & 0,560 & 3904,370 \\
\hline
\end{tabular}




\begin{tabular}{|c|c|c|c|c|c|c|c|c|c|}
\hline Iğdır & 69 & 72 & 0,376 & 0,453 & 1,310 & 0,700 & 1,093 & 0,390 & 244,473 \\
\hline Isparta & 2 & 1 & 0,467 & 0,600 & 0,830 & 1,350 & 0,668 & 0,690 & 1510,873 \\
\hline İstanbul & 56 & 5 & 3,331 & 2,047 & 0,920 & 1,120 & 1,245 & 1,300 & 148377,365 \\
\hline İzmir & 31 & 21 & 1,684 & 1,463 & 0,790 & 1,230 & 1,005 & 0,950 & 31301,062 \\
\hline Kahramanmaraş & 61 & 48 & 0,443 & 0,516 & 1,210 & 0,800 & 1,169 & 0,560 & 1224,362 \\
\hline Karabük & 9 & 12 & 0,420 & 0,638 & 0,750 & 1,660 & 0,695 & 0,690 & 685,194 \\
\hline Karaman & 23 & 25 & 0,532 & 1,065 & 0,990 & 1,000 & 0,720 & 0,910 & 563,089 \\
\hline Kars & 71 & 70 & 0,210 & 0,339 & 1,200 & 0,380 & 0,768 & 0,390 & 413,765 \\
\hline Kastamonu & 37 & 36 & 0,390 & 0,249 & 0,740 & 1,070 & 1,353 & 0,470 & 958,692 \\
\hline Kayseri & 43 & 42 & 0,877 & 1,012 & 1,050 & 1,250 & 1,061 & 0,780 & 2969,588 \\
\hline Kırıkkale & 35 & 9 & 1,145 & 0,848 & 0,880 & 0,950 & 0,672 & 0,690 & 517,507 \\
\hline Kırklareli & 13 & 32 & 0,671 & 0,344 & 0,680 & 1,180 & 0,702 & 0,520 & 1848,547 \\
\hline Kurşehir & 4 & 28 & 0,373 & 0,299 & 0,890 & 1,010 & 0,745 & 0,690 & 566,097 \\
\hline Kilis & 59 & 67 & 0,468 & 0,562 & 1,190 & 0,870 & 0,926 & 0,820 & 105,496 \\
\hline Kocaeli & 39 & 23 & 1,381 & 0,954 & 0,960 & 1,530 & 0,924 & 0,820 & 6353,349 \\
\hline Konya & 41 & 18 & 0,822 & 0,967 & 1,040 & 1,260 & 0,965 & 0,910 & 4289,449 \\
\hline Kütahya & 20 & 4 & 0,629 & 0,960 & 0,780 & 1,320 & 0,746 & 0,690 & 965,349 \\
\hline Malatya & 34 & 53 & 0,679 & 0,721 & 1,030 & 1,020 & 0,969 & 0,780 & 1516,455 \\
\hline Manisa & 47 & 31 & 0,650 & 0,771 & 0,850 & 0,960 & 0,804 & 0,690 & 3928,820 \\
\hline Mardin & 76 & 80 & 0,219 & 0,165 & 1,460 & 0,620 & 1,367 & 0,560 & 464,737 \\
\hline Mersin & 17 & 59 & 1,070 & 0,745 & 1,010 & 0,900 & 1,099 & 0,910 & 6740,160 \\
\hline Muğla & 26 & 45 & 1,114 & 1,206 & 0,780 & 1,230 & 0,773 & 0,820 & 7491,438 \\
\hline Muş & 77 & 81 & 0,062 & 0,075 & 1,520 & 0,110 & 0,968 & 0,210 & 192,715 \\
\hline Nevşehir & 15 & 37 & 0,501 & 1,151 & 0,950 & 0,710 & 0,655 & 0,690 & 643,699 \\
\hline Niğde & 42 & 51 & 0,383 & 0,391 & 1,060 & 0,710 & 0,709 & 0,690 & 668,802 \\
\hline Ordu & 49 & 55 & 0,550 & 0,498 & 0,890 & 0,590 & 0,828 & 0,520 & 1711,106 \\
\hline Osmaniye & 52 & 66 & 0,757 & 0,680 & 1,150 & 0,930 & 1,052 & 0,560 & 665,311 \\
\hline Rize & 27 & 14 & 0,643 & 0,529 & 0,850 & 0,930 & 0,704 & 0,520 & 781,864 \\
\hline Sakarya & 38 & 2 & 0,908 & 1,170 & 0,930 & 1,420 & 0,879 & 0,820 & 2154,602 \\
\hline Samsun & 22 & 33 & 0,743 & 0,776 & 0,920 & 0,840 & 0,835 & 0,820 & 3583,155 \\
\hline Siirt & 66 & 65 & 0,111 & 0,088 & 1,530 & 0,620 & 1,046 & 0,560 & 204,839 \\
\hline Sinop & 32 & 11 & 0,615 & 0,463 & 0,770 & 0,750 & 0,751 & 0,470 & 622,816 \\
\hline Sivas & 55 & 40 & 0,379 & 0,579 & 0,960 & 0,700 & 0,773 & 0,780 & 1452,262 \\
\hline Şanlıurfa & 78 & 73 & 0,260 & 0,218 & 1,570 & 0,610 & 1,277 & 0,390 & 931,485 \\
\hline Şırnak & 80 & 78 & 0,187 & 0,070 & 1,600 & 0,590 & 1,094 & 0,560 & 199,364 \\
\hline Tekirdağ & 46 & 30 & 1,218 & 0,659 & 0,860 & 1,350 & 0,964 & 0,520 & 3888,232 \\
\hline Tokat & 21 & 39 & 0,250 & 0,288 & 0,950 & 0,920 & 0,783 & 0,820 & 866,782 \\
\hline Trabzon & 19 & 20 & 0,628 & 0,551 & 0,870 & 1,200 & 0,789 & 0,520 & 2698,463 \\
\hline Tunceli & 1 & 62 & 0,881 & 1,436 & 0,590 & 1,070 & 0,583 & 0,780 & 372,278 \\
\hline Uşak & 30 & 6 & 0,440 & 0,607 & 0,840 & 1,060 & 0,772 & 0,690 & 1472,128 \\
\hline Van & 75 & 71 & 0,220 & 0,302 & 1,500 & 0,510 & 1,144 & 0,210 & 728,880 \\
\hline Yalova & 5 & 16 & 1,080 & 1,046 & 0,830 & 1,420 & 0,851 & 0,820 & 1020,648 \\
\hline Yozgat & 58 & 57 & 0,327 & 0,319 & 1,008 & 0,480 & 0,717 & 0,780 & 671,715 \\
\hline Zonguldak & 60 & 41 & 0,548 & 0,697 & 0,820 & 0,760 & 0,781 & 0,690 & 2746,466 \\
\hline
\end{tabular}

